VAN EICKELS, Klaus: "Regards croisés Africa Europe”: a new online journal of human and cultural sciences for the cooperation between Africa and Europe, in: Regards croisés Africa-Europe 1 (2021), pp. 13-16

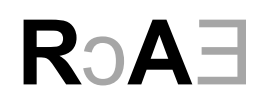

University of Bamberg Press - ISSN : 2749-8514

DOI: https://doi.org/10.20377/rcae-7

(finalisé: 30/11/2021 - publié: 15/12/2021)

\title{
"Regards croisés Africa-Europe": a new online journal of human and cultural sciences for the cooperation between Africa and Europe
}

\section{Résumé}

La revue « Regards croisés Afrique Europe » (acronyme : RcAE ; logo : $\mathbf{R} \supset \mathbf{A} \exists$ ), issu de la coopération de l'Université de Bamberg avec l'Afrique et éditée par les éditions de l'Université Bamberg (University of Bamberg Press, Allemagne), publie des contributions à la recherche sur l'histoire, littérature, linguistique et civilisation, pédagogie, théologie, philosophie et filières voisines des sciences culturelles et des sciences de l'homme. Les langues de publication sont le français, l'allemand et l'anglais. Sont particulièrement bienvenues les contributions transcendant les limites entre les époques, espaces géographiques et domaines de recherches établis.

\section{Zusammenfassung}

Die Zeitschrift "Regards croisés Afrika-Europa" (Akronym: RcAE; Logo: $\mathbf{R} \supset \mathbf{A} \exists$ ), hervorgegangen aus der Afrikakooperation der Otto-Friedrich-Universität Bamberg und herausgegeben von der University of Bamberg Press, veröffentlicht Forschungsbeiträge zu Geschichte, Literatur, Sprach- und Kulturwissenschaft, Pädagogik, Theologie, Philosophie und verwandten Bereichen der Kultur- und Humanwissenschaften. Die Publikationssprachen sind Französisch, Deutsch und Englisch. Beiträge zu übergreifenden Fragestellungen, die die klassischen Grenzen der Epochen, Untersuchungsräume und Forschungsgebiete überschreiten, sind besonders willkommen.

category: original article 


\begin{abstract}
The journal "Regards croisés Africa-Europe" (acronym: RcAE; logo: $\mathbf{R} \triangle \mathbf{A} \exists$ ), originating from the cooperation of the University of Bamberg with Africa and edited by the University of Bamberg Press (Germany), publishes research contributions on history, literature, linguistics and culture, pedagogy, theology, philosophy and related fields of cultural and human sciences. The languages of publication are French, German and English. Contributions that transcend the boundaries between eras, geographical areas and established fields of research are particularly welcome.
\end{abstract}

\title{
Contact
}

contact de l'auteur/Autorkontakt/author contact: klaus.van-eickels@uni-bamberg.de contact de la revue/Kontakt Zeitschrift/journal contact: redaktion.rcae@uni-bamberg.de journal homepage : https://ubp.uni-bamberg.de/rcae/index.php/rcae

Klaus VAN EICKELS est professeur titulaire d'histoire médiévale à l'Université de Bamberg (Allemagne). Ses recherches portent principalement sur l'histoire des liens interpersonnels (amour, mariage, amitié et fidélité vassalique) au Moyen Âge et sur l'histoire des sexualités à travers les époques.

Klaus VAN EICKELS ist Inhaber des Lehrstuhls für Mittelalterliche Geschichte an der OttoFriedrich-Universität Bamberg. Seine Forschungsschwerpunkte sind die Geschichte der personalen Bindungen (Liebe, Ehe, Freundschaft und Lehenstreue) im Mittelalter und die epochenübergreifende Geschichte der Sexualitäten.

Klaus VAN EICKELS is full professor of medieval history at the Otto Friedrich University of Bamberg (Germany). His research focuses on the history of personal bonds (love, marriage, friendship and fealty) in the Middle Ages and on the history of sexualités across epochs. 
The journal "Regards croisés Africa-Europe" (acronym: RcAE; logo: $\mathbf{R} \supset \mathbf{A} \exists$ ), originating from the cooperation of the University of Bamberg with Africa and edited by the University of Bamberg Press (Germany), publishes research contributions on history, literature, linguistics and civilization, pedagogy, theology, philosophy, and related fields of cultural and human sciences that fall into the following categories:

- Articles originaux / Originalaufsätze / Original articles

- Articles traduits / Aufsätze in Übersetzung/Articles in translation

- Articles mis à jour / Aktualisierte Aufsätze / Updated articles

- Conférences / Vorträge / Papers

- Materiels de cours / Unterrichtsmaterialien / Course materials

- Documents et sources / Dokumente und Quellen / Documents and sources

- Comptes rendus de colloques / Tagungsberichte / Conference abstracts

- Projets de recherches / Forschungsprojekte / Research Projects

- Positions de thèses de master et de doctorat/ Zusammenfassungen von Abschlussarbeiten und Dissertationen/ Abstracts of master and doctoral theses.

The languages of publication are French, German, and English. All scholars, researchers, doctoral students, and candidates for master's degrees in history, German/English/French or African languages, pedagogy, theology, philosophy and related fields are invited to submit their contributions. Contributions that transcend the boundaries between eras, geographical areas and established fields of research are particularly welcome.

The main distribution channel is the online publication of articles on the OPUS server of the University of Bamberg (Germany). Contributions approved for publication are immediately made available to readers as electronic versions. A printable version of the completed volumes in PDF format will be produced at the end of each completed year.

The journal is edited by a scientific committee of professors from the University of Bamberg and its partner universities in Africa and Europe 
as board of editors. The reading committee will include scholars from African and European universities and research experts of equivalent qualification. The board of editors and under its supervision the reading committee will ensure the academic quality of the contributions. The evaluation procedure will be open peer review, so that the authors can exchange openly with the reviewers and integrate their remarks mentioning their names. The original articles will be submitted to the appreciation of at least two specialists, if possible one from Africa and one from Europe. The articles will also be made available to the entire reading committee for further evaluation and comments. However, the authors of the contributions remain solely responsible for the respect of copyright and content.

As the journal is the result of the cooperation of the University of Bamberg with several universities mostly from French speaking or bilingual countries of Sub-Saharan Africa, it has been designed as a platform for communication and academic exchange in French, German and English between African and European scholars and doctoral students. Articles and thesis abstracts from young African researchers are particularly welcome. The journal does not limit itself to the publication of original articles. Translations and expanded and/or updated versions of articles published elsewhere, as well as conferences, course materials, documents and sources, conference proceedings, research projects and abstracts of master and doctoral theses are also welcome.

The journal will be accompanied by a series of "Regards croisés Africa-Europe. Supplements" for the publication of monographs (theses and others) as well as collective works (proceedings of colloquia and others). However, the regulations of the "University of Bamberg Press" require that theses can only be published if they have been supervised or co-supervised by a professor from the University of Bamberg. Monographs and collective volumes can only be published if a member of the University of Bamberg has made a substantial contribution as author, co-author, editor, co-editor, or contributor. 